\title{
Residues of pirimiphos-methyl and profenofos on green pepper and eggplant fruits and their effect on some quality properties
}

\author{
M. A. Radwan*, M. H. Shiboob, M. M. Abu-Elamayem and A. Abdel-Aal \\ Pesticide Chemistry Department, Faculty of Agriculture (El-Shatby), University of \\ Alexandria, Alexandria, Egypt.
}

\begin{abstract}
The residue levels of the two organophosphorus insecticides, pirimiphos-methyl and profenofos in fruits of green pepper and eggplant in relation to their effects on some internal quality properties were studied. The results showed that a waiting period of 10 and 14 days after application on green pepper and eggplant is enough to reduce the pirimiphos-methyl or profenofos residues, respectively, to below the maximum residue limits (MRL). However, profenofos appeared to have relatively longer persistence with $t_{112}$ of 1.74 and 1.96 days than pirimiphosmethyl with 1.72 and 1.88 days on pepper and eggplant fruits, respectively. As for the internal quality parameters of green pepper, pirimiphos-methyl treated fruit exhibited a significant increase in the total soluble sugars, $\%$ dry matter, total protein and $\beta$-carotene content. The profenofos treatment, significantly decreased the total soluble sugars, \% dry matter and total protein and has no adverse effect on the $\%$ acidity, ascorbic acid and $\beta$-carotene content. Both insecticide residues increased ascorbic acid content and decreased the total soluble sugars, \% acidity, T.S.S. in eggplant fruit. Also, the results showed that there were effects of varying degree by both insecticide residues on the levels of fatty acids and amino acids in tested vegetable fruits.
\end{abstract}

Keywords: Eggplant, green pepper, pirimiphos-methyl, profenofos, quality, residues.

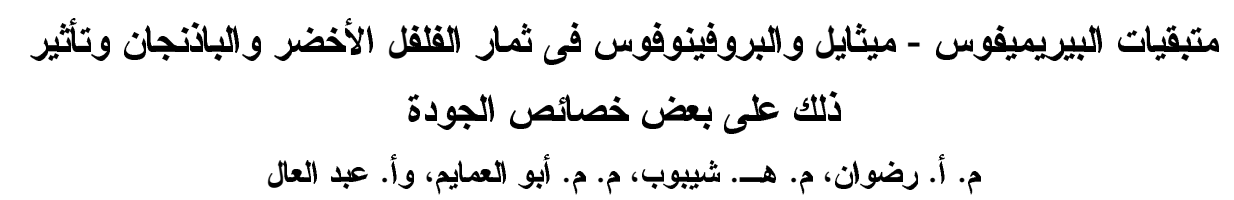

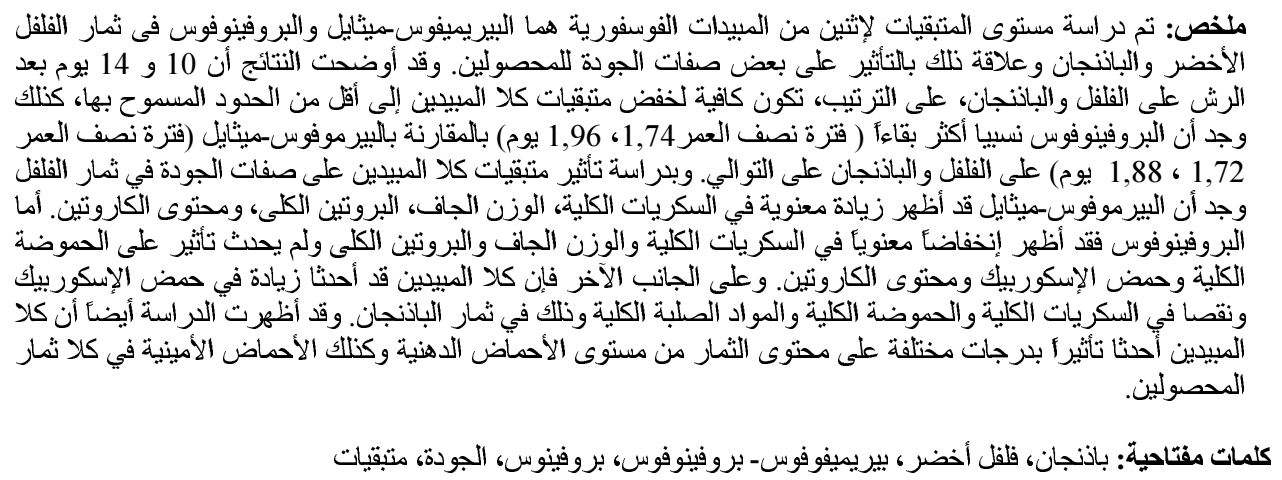

\section{Introduction}

Production and export of horticultural products are increasing rapidly in many developing countries. From 1970 to 2002, fruit and vegetable production in developing countries almost quadrupled from 256 to 960 million metric tons, while exports more than tripled from 1.9 to 6.5 million metric tons (Norton et al., 2003). Rapid growth in horticultural production has been accompanied by heavy use of pesticides and by heightened concern over health effects associated with pesticide use and abuse. Potential food safety risks from pesticide residues are a significant issue for importers of fresh vegetables and fruits and a market-risk factor for exporters who may have shipments detained or rejected if residues exceed allowable limits. Egypt is among the countries adopting the FAO/WHO internationally established Maximum Residue Limit (MRLs) for some pesticides on different crops. However, 
there are pesticides without recommended MRLs, especially those not important to international trade. With the opening up of Egypt to world trade, it is necessary to generate residue data for pesticides in use to establish our local MRLs and to protect consumers from adverse side effects. Green pepper and eggplant are considered as an important part of edible vegetable production in Egypt. Generally, these vegetable varieties are attacked by a number of insects and diseases which require frequent use of pesticides. Pirimiphos-methyl and profenofos are organophosphorus insecticides widely used to control various insect pests including leaf worms, aphids, leafhoppers, whiteflies and thrips on pepper and eggplant. There is a lack of published data in Egypt for the fate of pirimiphos-methyl and profenofos on these vegetable crops. Therefore, assessment of their residues on pepper and eggplant fruits is of great concern. The present work was carried out in an attempt to: (1) study the persistence of pirimiphosmethyl and profenofos on green pepper and eggplant fruits, and (2) investigate the effect of the two tested insecticide residues on some quality parameters of fruit.

\section{Materials and Methods}

Insecticides used

Pirimiphos-methyl; $\quad$ O-(2-diethylamino-6-methyl pyrimidin-4-yl) O,Odimethyl phosphorothioate with acute oral $\mathrm{LD}_{50}$ of $1180 \mathrm{mg} / \mathrm{kg}$ for rats, technical grade sample with purity of $99.8 \%$ provided by ICI PLC, Plant Protection Division, UK. and profenofos; O-(4-bromo-2chlorophenyl)- O-ethyl-S-propyl phosphorothioate with acute oral $\mathrm{LD}_{50}$ of $400 \mathrm{mg} / \mathrm{kg}$ for rats, technical grade with purity of $99 \%$ obtained from Ciba Geigy Ltd. (Swizerland), were used for GLC standardization in the present study. The emulsifiable concentrate $50 \%$ of pirimiphos-methyl and $72 \%$ of profenofos was employed in the field experiment.

Field experiment and sampling:

Field experiments were conducted during the summer in the Abees area, Alexandria Governorate, Egypt. Plots consisting of 10 rows separated by a 3 row belt of green pepper (Capsicum annuum L.) var. California wonder and eggplant (Solanum melongena L.) var. Balady were allocated to randomized blocks with three replicates. Mature plants were sprayed with pirimiphos-methyl or profenofos once at the recommended rate of at $750 \mathrm{~cm}^{3} /$ feddan (feddan $=0.42$ hectare), 2 days before the first harvesting. Spraying was carried out using a knapsack-sprayer ( $\mathrm{Cp}-3)$ provided with one nozzle delivering 200 liters water/feddan, which has proved to be sufficient to give good coverage on the treated plants. Unsprayed control plots were included for each treatment. All agricultural management practices were made as usually practiced in commercial production of pepper or eggplant. Fruit samples were randomly collected (500 gm were sampled per replicate). Fruit samples were taken at intervals of $0(1 \mathrm{hr}), 1,3,5$, 7, 10 and 14 days after application. The collected samples were placed in plastic bags and frozen at $18^{\circ} \mathrm{C}$ until insecticide residue analysis was run.

\section{Extraction and clean up}

For extraction of pirimiphos-methyl and profenofos residues, the chopped fruit samples (50 gm sub-samples) were taken and extracted with acetone $(150 \mathrm{ml})$ for three minutes followed by partitioning using dichloromethane (Bowman, 1980). The resulting extracts were evaporated to near dryness using a rotary evaporator at $35^{\circ} \mathrm{C}$. The concentrate was taken in $1 \mathrm{ml}$ n-hexane for clean-up. The extracts were cleaned-up in a silica gel column 
amended with $1 \mathrm{gm}$ activated charcoal using $20 \%$ acetone in n-hexane as an eluting solvent (Bowman and Leuck, 1971), after which they were again concentrated and stored in the freezer until residue analysis.

To examine the efficacy of extraction and clean-up, three samples from each fruit type were spiked with known concentration $(2 \mathrm{mg} / \mathrm{kg})$ of the pure insecticide standard solution. Extraction and clean-up were performed as described earlier and the average recovery rates were found to be 88.40 and $85.53 \%$ for pepper and eggplant fruits treated with pirimiphos-methyl, respectively. The corresponding recoveries were found to be 94.35 and $73.10 \%$ for fruits treated with profenofos. Results were corrected according to the average of recovery.

\section{Residue determination}

Determination of pirimiphos-methyl and profenofos residues was performed on a Shimadzu 4-CM (PFE) GC. FPD with an analytical glass column $(2 \mathrm{~m} \times 3 \mathrm{~mm}$ i.d) packed with $4 \%$ SE-30 $+6 \%$ OV-210 on 80/100 Chromosorb W. The operating temperatures $\left({ }^{\circ} \mathrm{C}\right)$ for both tested insecticides were maintained as follows: Column 220 isothermal, injector 270, detector 270 and gas flow rate $(\mathrm{ml} / \mathrm{min})$ were: nitrogen 40 , hydrogen 80 and air 100; the limits of detection under these conditions were 0.30 and $2.8 \mathrm{ng}$ for pirimiphos-methyl and profenofos, respectively. Identification of each tested insecticide residue was accomplished by retention time $\left(t_{R}\right)$ and compared with known standards at the same conditions. The quantities were calculated on a peak height basis. Using these conditions, the retention times of pirimiphos-methyl and profenofos were 8.6 and 11 minutes, respectively.
Determination of some internal quality parameters

Analytical determination for the studied chemical quality parameters was made on treated and untreated fruit to evaluate the side effect of the tested insecticide residues on the quality of fruit. These chemical parameters included total soluble sugars which were determined colourimetrically using the picric acid method as described by Thomas and Dutcher (1924); \% acidity, ascorbic acid (vitamin $\mathrm{C}$ ), \% dry matter and protein content were determined according to the methods of AOAC (1984). Total soluble solids (T.S.S.) were estimated using a refractometer. $\beta$-carotene was determined by the method of Ben-Amotza and Avron (1983); fatty acid content was determined according to Radwan (1978), using GC after the conversion of fatty acid into fatty acid methyl esters and amino acids content was determined using amino acid analyzer according to the method of Moore et al., (1958).

\section{Statistical Analysis}

Statistical significance of the data was determined by the analysis of variance with the LSD method at probability of 0.05 (Steel and Torrie, 1980).

\section{Results and Discussion}

Insecticide residues

Green pepper and eggplant crops were sprayed at fruit set with pirimiphos-methyl or profenofos using a recommended field rate to study the persistence of such insecticides at different intervals.

Results in Table (1) showed that the initial deposits of pirimiphos-methyl and profenofos in/on pepper fruit had approximately the same level of deposit, one hour after spraying $(\approx 10.5 \mathrm{ppm})$. 
Table 1. Residues of pirimiphos-methyl and profenofos in green pepper and eggplant fruits at periodic intervals.

\begin{tabular}{ccccc}
\hline \multirow{2}{*}{$\begin{array}{c}\text { Sampling } \\
\text { Days }\end{array}$} & \multicolumn{4}{c}{ Residue $^{\text {a }}$ [ug.g- ${ }^{\mathbf{1}}$ (\% Dissipation)] } \\
\cline { 2 - 5 } & Pirimiphos-methyl & Profenofos & \multicolumn{2}{c}{ Eggplant Fruit } \\
\hline $0(1 \mathrm{~h})^{\mathrm{b}}$ & 10.49 & 10.67 & 4.26 & 4.50 \\
1 & 5.61 & 5.73 & 2.89 & 3.30 \\
& $(46.52)$ & $(46.29)$ & $(32.16)$ & $(26.67)$ \\
3 & 4.07 & 3.42 & 1.16 & 1.49 \\
& $(61.20)$ & $(67.95)$ & $(62.21)$ & $(66.89)$ \\
5 & 2.09 & 2.59 & 0.85 & 0.79 \\
& $(80.08)$ & $(75.73)$ & $(80.05)$ & $(82.44)$ \\
7 & 0.77 & 0.91 & 0.40 & 0.27 \\
& $(92.66)$ & $(91.48)$ & $(90.61)$ & $(94.00)$ \\
10 & 0.36 & 0.31 & 0.07 & 0.15 \\
& $(96.57)$ & $(97.09)$ & $(98.38)$ & $(96.97)$ \\
14 & 0.021 & $\mathrm{ND}$ & 0.01 & $\mathrm{ND}$ \\
& $(99.79)$ & $(\approx 100)$ & $(99.77)$ & $(\approx 100)$ \\
\hline
\end{tabular}

${ }^{\mathrm{a}}$ Mean of three replicates.

${ }^{\mathrm{b}}$ Initial deposits of the insecticide.

${ }^{\mathrm{c}}$ ND Not detected.

A rapid degradation of insecticide residues was noticed with pirimiphos-methyl and profenofos, one day after application, at 46.52 and $46.29 \%$ loss, respectively. The first week was critical, showing the highest rate of dissipation from pepper fruit, at 92.66 and $91.48 \%$ with pirimiphos-methyl and profenofos, respectively. By the end of experiment (two weeks), fruit contained negligible residues of $0.021 \mathrm{ppm}$ for pirimiphos-methyl, whereas no residues were detected for profenofos at that time representing 99.79 and $\approx 100 \%$ loss, respectively.

The extractable residues of pirimiphosmethyl in/on eggplant fruit ranged from 4.26 ppm (one hour after application) to $0.40 \mathrm{ppm}$ in 7 days samples when applied at the field rate. The percent of dissipation at 1 and 7 days was found to be 32.16 and $90.61 \%$ respectively. The corresponding average residues of profenofos ranged from 4.50 to $0.27 \mathrm{ppm}$ at zero time to 7 days and the dissipation ranged from 26.67 to $94.00 \%$ for 1 and 7 days, respectively. After two weeks, no detectable residues of profenofos were measured on eggplant fruit, but a negligible amount $(0.01 \mathrm{ppm})$ of pirimiphos-methyl remained at that time.

The calculated half-life values of pirimiphos-methyl were 1.72 and 1.88 days on pepper and eggplant fruits, respectively. The corresponding half life values of profenofos were 1.74 and 1.96 days, respectively (Table 2 ).

Table 2. The value of apparent rate constant $(K)$ and half-life time $\left(t_{1 / 2}\right)$ of tested insecticides on green pepper and eggplant fruits using GC method.

\begin{tabular}{|c|c|c|c|}
\hline Insecticide & Sample & Apparent Rate Constant (k) & Half-Life Time $\left(t_{1 / 2}\right)^{b}$ (Day) \\
\hline \multirow{2}{*}{ Pirimiphos-methyl } & Pepper & 0.40 & 1.72 \\
\hline & Eggplant & 0.37 & 1.88 \\
\hline \multirow{2}{*}{ Profenofos } & Pepper & 0.40 & 1.74 \\
\hline & Eggplant & 0.35 & 1.96 \\
\hline
\end{tabular}


It could be concluded that $0.3 \mathrm{ppm}$ of pirimiphos-methyl or profenofos residues was detected on pepper fruit, 10 days after application. This indicated that 10 days was long enough to reduce the residue of each insecticide below the permissible residue limits, pirimiphos-methyl (1ppm) and profenofos (0.5 ppm) on pepper (Codex Alimentaries Commission, 1999). Also, the negligible amount $(0.01 \mathrm{ppm})$ of pirimiphosmethyl was detected on eggplant fruit after 14 days of spraying, while profenofos was undetectable at that time. The Codex MRLs for profenofos and pirimiphos-methyl residues in/on several commodities ranged from 0.05 to $2 \mathrm{mg} / \mathrm{kg}$ and 0.05 to $20 \mathrm{mg} / \mathrm{kg}$, respectively (Codex Alimentaries Commission, 1999). The list, however, lacks MRLs for each insecticide on eggplant. Therefore, eggplant fruit could be marketed with apparent safety for human consumption when free from any residues of profenofos or pirimiphos-methyl.

The present results of pirimiphosmethyl and profenofos residues on pepper and eggplant fruits are comparable to those reported in earlier studies; the initial deposits of profenofos in/on unwashed tomato and okra fruits were 10.18 and $11.56 \mathrm{ppm}$, respectively. Whereas that of pirimiphos-methyl were 13.71 and 14.24 ppm, respectively. These figures were decreased to $0.04 \& 0.025$ and $0.049 \&$ $0.56 \mathrm{ppm}$ after 15 days of spraying (Ramadan, 1991). Tomatoes treated with pirimiphos-methyl could be marketed one day after application, after 8 days when fruit is treated with profenofos. Green beans, could be consumed safely 4 and 11 days after spraying with pirimiphos-methyl and profenofos, respectively (Abd-Alla et al., 1993). Minute amounts $(0.02 \mathrm{ppm})$ of profenofos were detected in pods of cowpea 15 days after spraying, while pirimiphosmethyl was undetectable in the whole pods after 10 days (Soliman, 1994). The level of pirimiphos-methyl or chloropyrifos-methyl residues on broad bean seeds was found to be within the MRL's 5 days after application, while exceeding the MRL's on tomatoes after 5 and 7 days of application, respectively (Radwan et al., 1995). The waiting period of 21 days after application of pirimiphos-methyl on grapes is enough to reduce residues to below the MRLs (Radwan et al., 2001).

Effect of pirimiphos-methyl and profenofos residues on internal quality parameters of green pepper and eggplant fruits

Pesticide residues may interfere with biochemical and physiological processes in plants retarding the growth of the plant and yield. Also, they may lower its food quality and may even prevent its use as food by affecting its quality characteristics (Bartholomew et al., 1951). So, the possible effect of pirimiphos-methyl and profenofos residues on chemical characteristics of green pepper and eggplant fruits was determined.

The data in Table (3) indicated that profenofos significantly decreased the total soluble sugars in pepper fruit throughout the experiment, whereas pirimiphos-methyl increased them. The average of total acid content expressed as \% citric acid was not affected by application of either pirimiphosmethyl or profenofos when compared to the untreated samples. The mean amount of T.S.S was significantly lower in fruit treated with pirimiphos-methyl and was not significantly affected by profenofos. Pirimiphos-methyl significantly increased dry matter and protein contents, yet decreased effect was noticed when fruit was treated with profenofos. No significant differences in ascorbic acid content of fruit, while $\beta$-carotene content significantly increased compared to the control when treated with pirimiphos-methyl. Profenofos did not show any significant effect on either parameter. 
Table (3): Effect of pirimiphos-methyl and profenofos on some Fruit Quality Parameters of Treated Green Pepper.

\begin{tabular}{llcl}
\hline \multicolumn{1}{c}{ Parameter } & Untreated & $\begin{array}{c}\text { Treatments }^{\mathrm{a}} \\
\text { Pirimiphos-methyl }^{\text {Pathos }}\end{array}$ & \multicolumn{1}{c}{ Profenofs } \\
\hline $\begin{array}{l}\text { Total soluble sugars }(\mathrm{mg} \\
\text { glucose/100gm) }\end{array}$ & $22.57 \pm 0.25 \mathrm{~b}$ & $23.31 \pm 0.20 \mathrm{a}$ & $20.57 \pm 0.05 \mathrm{c}$ \\
\% Acidity & $0.34 \pm 0.01 \mathrm{a}$ & $0.32 \pm 0.01 \mathrm{a}$ & $0.31 \pm 0.02 \mathrm{a}$ \\
T.S.S. & $5.18 \pm 0.09 \mathrm{a}$ & $4.53 \pm 0.24 \mathrm{~b}$ & $4.91 \pm 0.21 \mathrm{ab}$ \\
\% dry matter & $10.33 \pm 0.03 \mathrm{~b}$ & $11.47 \pm 0.45 \mathrm{a}$ & $8.86 \pm 0.00 \mathrm{c}$ \\
\% protein & $1.41 \pm 0.01 \mathrm{~b}$ & $1.57 \pm 0.06 \mathrm{a}$ & $1.23 \pm 0.02 \mathrm{c}$ \\
Ascorbic acid (mg/100gm) & $65.23 \pm 5.45 \mathrm{a}$ & $71.15 \pm 7.32 \mathrm{a}$ & $61.36 \pm 0.84 \mathrm{a}$ \\
$\beta$-carotene (mg/100gm) & $9.19 \pm 0.6 \mathrm{~b}$ & $12.69 \pm 0.06 \mathrm{a}$ & $9.87 \pm 0.77 \mathrm{~b}$ \\
\hline
\end{tabular}

${ }^{a}$ Each value in the treatments is a mean of three replicates \pm SD. Means followed by the same letter (s), in each row, are not significantly different (ANOVA, LSD test $\mathrm{P} \leq 0.05$ ).

Table 4. Effect of pirimiphos-methyl and profenofos on some fruit quality parameters of treated eggplant.

\begin{tabular}{lccc}
\hline \multirow{2}{*}{ Parameter } & Untreated & $\begin{array}{c}\text { Pirimiphos- } \\
\text { methyl }\end{array}$ & Profenofos \\
\cline { 2 - 4 } & $12.04 \pm 0.95 \mathrm{a}$ & $9.86 \pm 0.76 \mathrm{~b}$ & $8.65 \pm 0.08 \mathrm{c}$ \\
\hline $\begin{array}{l}\text { Total soluble sugars }(\mathrm{mg} \\
\text { glucose/100gm) }\end{array}$ & & \\
\% Acidity & $0.37 \pm 0.07 \mathrm{a}$ & $0.34 \pm 0.02 \mathrm{~b}$ & $0.29 \pm 0.03 \mathrm{c}$ \\
T.S.S. & $3.32 \pm 0.11 \mathrm{a}$ & $3.02 \pm 0.20 \mathrm{~b}$ & $2.95 \pm 0.31 \mathrm{~b}$ \\
$\%$ dry matter & $10.29 \pm 2.11 \mathrm{a}$ & $9.77 \pm 0.97 \mathrm{a}$ & $11.54 \pm 2.85 \mathrm{a}$ \\
$\%$ protein & $1.54 \pm 0.15 \mathrm{~b}$ & $1.88 \pm 0.05 \mathrm{ab}$ & $1.95 \pm 0.26 \mathrm{a}$ \\
Ascorbic acid (mg/100gm) & $4.64 \pm 0.92 \mathrm{~b}$ & $6.31 \pm 1.07 \mathrm{a}$ & $6.77 \pm 0.46 \mathrm{a}$ \\
\hline a Each value in the treatments is a mean of three replicates \pm SD. Mean followed by the same letter (s), \\
in each row are not significantly different (ANOVA, LSD test P $\leq 0.05)$.
\end{tabular}

Results in Table (4) showed that both insecticide residues significantly decreased total soluble sugars, $\%$ acidity and T.S.S. in eggplant fruit. The reduction effect was higher in profenofos than pirimiphosmethyl treated fruit when compared with the control. Pirimiphos-methyl did not produce any significant effect on dry matter and protein content compared with the control, but profenofos exhibited an increase in the protein content. Both compounds significantly increased ascorbic acid content in eggplant fruit.

It is well established that certain pesticides influence the chemical composition of the plants after they are applied. Profenofos residues increased protein and ascorbic acid content in potatoes (Habiba et al., 1992). Also, this compound increased T.S.S and acidity, but decreased the glucose, protein and ascorbic acid content of tomatoes (Ismail et al., 1993). Radwan et al., (1995) reported that pirimiphos-methyl residues appeared to have significant adverse effects on the total soluble sugars and ascorbic acid content of tomato fruit and broad bean seeds. Pirimiphos-methyl exhibited a significant increase on total soluble sugars and \% acidity of grape berries, whereas there was no effect on refractometric T.S.S. (Radwan et al., 2001). 
Emir. J. Agric. Sci. 2004. 16 (1) : 32-42

http://www.cfs.uaeu.ac.ae/research/ejas.html

Table 5. Effect of pirimiphos-methyl and profenofos residues on the percentage of tested fatty acids of treated crops.

\begin{tabular}{|c|c|c|c|c|c|c|}
\hline \multirow{2}{*}{ Fatty Acid } & \multicolumn{3}{|c|}{ Pepper fruit ${ }^{\mathrm{a}}$} & \multicolumn{3}{|c|}{ Eggplant fruit ${ }^{\mathrm{a}}$} \\
\hline & Control & Pirimiphos-methyl & Profenofos & Control & Pirimiphos-methyl & Profenofos \\
\hline Lauric C12:0 & $0.239 \mathrm{~b}$ & $0.745 \mathrm{a}$ & $0.210 \mathrm{~b}$ & $0.69 \mathrm{a}$ & $0.92 \mathrm{a}$ & $0.63 \mathrm{a}$ \\
\hline Myristic C14:0 & $0.671 \mathrm{a}$ & $0.778 \mathrm{a}$ & $0.822 \mathrm{a}$ & $0.65 \mathrm{a}$ & $0.61 \mathrm{a}$ & $0.65 \mathrm{a}$ \\
\hline Palmitic C16:0 & $15.108 \mathrm{~b}$ & $17.001 \mathrm{ab}$ & $20.633 \mathrm{a}$ & $28.79 \mathrm{a}$ & $21.75 \mathrm{~b}$ & $23.41 \mathrm{ab}$ \\
\hline Palmitolitic C16:1 & $0.565 \mathrm{a}$ & $0.361 \mathrm{~b}$ & $0.675 \mathrm{a}$ & $0.94 \mathrm{a}$ & $0.23 \mathrm{~b}$ & $0.29 \mathrm{~b}$ \\
\hline Stearic C18:0 & $4.869 \mathrm{a}$ & $4.570 \mathrm{a}$ & $6.545 \mathrm{a}$ & $12.84 \mathrm{a}$ & $9.87 \mathrm{a}$ & $11.84 \mathrm{a}$ \\
\hline Oleic C18:1 & $10.169 \mathrm{a}$ & $9.595 \mathrm{a}$ & $8.556 \mathrm{a}$ & $12.68 \mathrm{~b}$ & $20.44 \mathrm{a}$ & $20.61 \mathrm{a}$ \\
\hline Linoleic C18:2 & $60.302 \mathrm{ab}$ & $61.842 \mathrm{a}$ & $54.479 \mathrm{~b}$ & $36.34 \mathrm{a}$ & $37.85 \mathrm{a}$ & $34.43 \mathrm{a}$ \\
\hline Linolenic C18:3 & $1.351 \mathrm{a}$ & $0.901 \mathrm{a}$ & $1.600 \mathrm{a}$ & $1.24 \mathrm{a}$ & $1.13 \mathrm{a}$ & $1.12 \mathrm{a}$ \\
\hline Arachidic C20:0 & $5.313 \mathrm{~b}$ & $3.398 \mathrm{c}$ & $5.691 \mathrm{a}$ & $4.94 \mathrm{~b}$ & $5.99 \mathrm{a}$ & $5.77 \mathrm{a}$ \\
\hline Behenic C22:0 & $1.474 \mathrm{a}$ & $1.029 \mathrm{a}$ & $0.848 \mathrm{a}$ & $0.93 \mathrm{a}$ & $0.71 \mathrm{a}$ & $1.10 \mathrm{a}$ \\
\hline Saturated \% & $27.613 \mathrm{a}$ & $27.477 \mathrm{a}$ & $34.683 \mathrm{a}$ & $48.82 \mathrm{a}$ & $39.84 \mathrm{~b}$ & $43.40 \mathrm{ab}$ \\
\hline Unsaturated \% & $72.387 \mathrm{a}$ & $72.480 \mathrm{a}$ & $65.317 \mathrm{a}$ & $51.18 \mathrm{~b}$ & $60.16 \mathrm{a}$ & $56.60 \mathrm{ab}$ \\
\hline
\end{tabular}


Effect on the percentage of fatty acids content

The effect of pirimiphos-methyl and profenofos residues on the percentage of tested fatty acids of pepper and eggplant fruits was recorded in Table (5). Pirimiphos-methyl residues significantly increased the level of lauric acid and decreased that of palmitolitic and arachidic acids. On the other hand, profenofos significantly increased the level of palmitic and arachidic acids. No significant differences were found between the two tested treatments and the control for their effects on the percentage of saturated and unsaturated fatty acids.

Both insecticidal treatments caused significant increase or decrease in the level of some fatty acids in eggplant fruit. Profenofos increased the level of oleic and arachidic acids and only decreased the level of palmitolitic acid. Also, pirimiphosmethyl increased the above two fatty acids as profenofos and decreased palmitolitic plus palmitic acids. Profenofos caused no significant changes in the level of saturated and unsaturated fatty acids, whereas pirimiphos-methyl caused significant decreases and increases in saturated and unsaturated fatty acids, respectively. These results are supported with those reported by Azhogina et al., (1991 and 1996). They indicated that the two organophosphorus insecticides, phosalan and metaphos decreased the total level of lipids, changed the ratio of saturated and unsaturated fatty acids, decreased the level of palmitic and palmitoletic acids and increased the level of behenic and erucic acids when added to grape juice, malts or wine.

\section{Effect on the total amino acids}

The effect of pirimiphos-methyl and profenofos residues on total amino acid patterns of green pepper and eggplant fruits are presented in Table (6). It was observed that both of the tested insecticides did not cause any significant effect on total amino acids. Pirimiphos-methyl significantly decreased the levels of threonine, proline, alanine, valine, isoleucine, leucine, tyrosine and phenylalanine, while causing an increase in the level of arginine when compared to the untreated pepper fruit. This insecticide significantly increased the level of proline and arginine, while decreasing the level of threonine and methionine in eggplant fruit. On the other hand, profenofos significantly decreased alanine, isoleucine, leucine and phenylalanine in pepper fruit, whereas it caused a significant increase in the levels of proline and arginine plus glutamic acid, histidine and lysine when compared to the untreated eggplant fruit. The observed increases of amino acids may be the result of an increased rate of synthesis of amino acids, an increased rate of degradation of proteins, or both. The level of amino acids and the capacity of the levels of treated insecticides to reduce nitrate (through nitrate reductase) and synthesize amino acids (through glutamic acid dehydrogenase, transaminase, respiratory enzymes, pyruvate kinase and cytochrome oxidase) apparently led Bidwell et al., (1964) to believe that such insecticides induce efficient synthesis of amino acids.

In conclusion, the present study provides residue data which may be used to propose MRL's for these insecticides on vegetables under Egyptian field conditions and suggests the need for implementation of these safety intervals before harvesting and marketing such crop fruit, and the possible effect on fruit quality that should be considered to avoid problems which may arise as a result of side effects of insecticides. 
Emir. J. Agric. Sci. 2004. 16 (1) : 32-42

http://www.cfs.uaeu.ac.ae/research/ejas.html

Table 6. Effect of pirimiphos-methyl and profenofos residues on the total amino acids $(\mathrm{mg} / 100 \mathrm{gm}$ protein) of treated crops.

\begin{tabular}{|c|c|c|c|c|c|c|}
\hline \multirow{2}{*}{ Amino acid } & \multicolumn{3}{|c|}{ Pepper fruit ${ }^{\mathrm{a}}$} & \multicolumn{3}{|c|}{ Eggplant fruit $^{\mathbf{a}}$} \\
\hline & Control & Pirimiphos-methyl & Profenofos & Control & Pirimiphos-methyl & Profenofos \\
\hline Aspartic acid & $8.54 \mathrm{a}$ & $9.74 \mathrm{a}$ & $9.41 \mathrm{a}$ & $5.53 \mathrm{a}$ & $5.38 \mathrm{a}$ & $6.31 \mathrm{a}$ \\
\hline Threonine & $3.53 \mathrm{a}$ & $2.94 \mathrm{~b}$ & $3.31 \mathrm{ab}$ & $2.97 \mathrm{a}$ & $2.52 \mathrm{~b}$ & $3.09 \mathrm{a}$ \\
\hline Glutamic acid & $8.24 \mathrm{a}$ & $10.05 \mathrm{a}$ & $8.30 \mathrm{a}$ & $6.42 \mathrm{~b}$ & $7.19 \mathrm{ab}$ & $8.12 \mathrm{a}$ \\
\hline Proline & $4.24 \mathrm{a}$ & $2.92 \mathrm{~b}$ & $4.20 \mathrm{ab}$ & $1.54 \mathrm{c}$ & $2.54 \mathrm{~b}$ & $3.23 \mathrm{a}$ \\
\hline Glycine & $2.74 \mathrm{a}$ & $2.70 \mathrm{a}$ & $2.52 \mathrm{a}$ & $2.44 \mathrm{a}$ & $2.00 \mathrm{a}$ & $2.26 \mathrm{a}$ \\
\hline Cystine & $0.31 \mathrm{a}$ & $0.18 \mathrm{a}$ & $0.22 \mathrm{a}$ & $0.04 \mathrm{a}$ & $0.05 \mathrm{a}$ & $0.03 \mathrm{a}$ \\
\hline Valine & $4.29 \mathrm{a}$ & $3.88 \mathrm{~b}$ & $4.11 \mathrm{ab}$ & $2.66 \mathrm{a}$ & $1.73 \mathrm{a}$ & $2.39 \mathrm{a}$ \\
\hline Methionine & $0.74 \mathrm{a}$ & $0.65 \mathrm{a}$ & $0.63 \mathrm{a}$ & $0.95 \mathrm{a}$ & $0.67 \mathrm{~b}$ & $0.83 \mathrm{ab}$ \\
\hline Isoleucine & $3.58 \mathrm{a}$ & $2.85 \mathrm{~b}$ & $3.06 \mathrm{~b}$ & $3.20 \mathrm{a}$ & $2.25 \mathrm{a}$ & $2.86 \mathrm{a}$ \\
\hline Leucine & $3.91 \mathrm{a}$ & $3.28 \mathrm{c}$ & $3.64 \mathrm{~b}$ & $3.89 \mathrm{a}$ & $3.24 \mathrm{a}$ & $3.87 \mathrm{a}$ \\
\hline Tyrosine & $2.39 \mathrm{a}$ & $1.98 \mathrm{~b}$ & $2.22 \mathrm{ab}$ & $1.29 \mathrm{a}$ & $1.12 \mathrm{a}$ & $1.28 \mathrm{a}$ \\
\hline Phenylalanine & $3.74 \mathrm{a}$ & $3.13 \mathrm{~b}$ & $3.31 \mathrm{~b}$ & $2.30 \mathrm{a}$ & $1.86 \mathrm{a}$ & $2.10 \mathrm{a}$ \\
\hline Lysine & $2.53 \mathrm{a}$ & $2.19 \mathrm{a}$ & $2.58 \mathrm{a}$ & $1.90 \mathrm{~b}$ & $1.97 \mathrm{~b}$ & $2.44 \mathrm{a}$ \\
\hline Arginine & $2.78 \mathrm{ab}$ & $3.51 \mathrm{a}$ & $2.72 \mathrm{~b}$ & $2.59 \mathrm{~b}$ & $3.15 \mathrm{a}$ & $3.39 \mathrm{a}$ \\
\hline Total & $60.93 \mathrm{a}$ & $58.46 \mathrm{a}$ & $59.25 \mathrm{a}$ & $44.29 \mathrm{a}$ & $41.64 \mathrm{a}$ & $48.62 \mathrm{a}$ \\
\hline
\end{tabular}

${ }^{\mathrm{a}}$ Each value in treated and untreated fruit in each crop is a mean of three replicates \pm SD. Means followed by the same letter (s), in each row for each crop, are not significantly different (ANOVA, LSD test $\mathrm{P} \leq 0.05$ ). 


\section{References}

Abd-Alla, E. F., E. A. Sammour S. A. Abd-Allah and E. El-Sayed. 1993. Persistence of some organophosphate insecticide residues on tomato and bean plants. Bull. Fac. Agric. Cairo Univ. 44(2): 462-476.

Anonymous. 1999. List of Codex Maximum Residue Limits. August, 31. WHO/FAO.

AOAC. 1984. Official Method of Analysis of the Association of Official Analytical Chemists, Sidny Williams. Ed. 14th Ed. Association of Official Analytical Chemists, Inc. Arlington, Virginia, U.S.A.

Azhogina, V. A., T. I. Guguchkina and N. M. Ageeva. 1991. Pesticide residues influence on the fatty acid composition of lipid complex in grape juice. Gig Sanit, 10: 51-52.( c.f. Chem. Abst. 1992, $116: 5439 \mathrm{y})$.

Azhogina, V. A., N. M. Ageeva and T.I. Guguchkina. 1996. Transformation of lipid complex of musts and wines under the action of pesticides. Pishch. Tekhnol., 5-6: 26-27. (c.f. Chem. Abst.1996,124 (19): 258968 d).

Bartholomew, E. T.; W. S. Stewart and G. E. Carman. 1951. Some phosiological effects of insecticides on citrus fruits and leaves. The Botanical Gazette 112 (4): 501-511.

Ben-Amotz, A. B. and M. Avron. 1983. On the factors which determine massive $\beta$ carotene accumulation in the halotolerant alga Dunaliella bardawil. Plant. Physiol. 72: 593-597.

Bidwell, R. G., S. R. A. Barr and F. C. Steward. 1964. Protein synthesis and turnover in cultured plant tissue: Sources of carbon for synthesis and the fate of the protein breakdown products. Nature 203: 367-373.

Bowman, M. C. 1980. Analysis of organophosphorus pesticides, In: H. A. Moye (Ed.). PP. 263-332. Analysis of Pesticide Residues. John Wiley \& Sons Inc.

Bowman, M. C. and D. B. Leuck. 1971. Determination and persistance of phoxim and its oxygen analog in forage corn and grass. J. Agric. Food Chem. 19 (6): 1215-1218.

Habiba, R.A., H. M. Ali and S. M. M. Ismail. 1992. Biochemical effects of profenofos residues in potatoes. J. Agric. Food Chem. 40: 1852-1855.

Ismail, S. M., H. M. Ali and R. A. Habiba. 1993. GC-ECD and GC-MS analysis of profenofos residues and biochemical effects in tomatoes and tomato products. J. Agric. Food Chem. 41: 610-615.

Moore, S.; D. H. Spackman and W. H. Stein. 1958. Chromatography of amino acids on sulfonated polystyrene resins. Anal. Chem. 30 (7): 1185-1190.

Norton, G.W., G. E. Sanchez D. C. Harris and H. K. Traore. 2003. Food safety in food security and food trade. Case study: Reducing pesticide residues on horticultural crops. International Food Policy Research Institute, Washington, D.C., U.S.A.

Radwan, M. A., M. H. Shiboob, A. AbdelAal and M. Abu-Elamayem. 2001. Residues of pirimiphos-methyl and fenitrothion in grapes, their effect on some quality properties and their dissipation during the removal and 
processing methods. J. Pest Cont. \& Environ. Sci. 9 (3): 89-107.

Radwan, M. A., M. M. Youssef A. Abd-ElAll, G. L. El-Henawy and A. Marei. 1995. Residue levels of pirimiphosmethyl and chlorpyrifos-methyl on tomato and faba bean plants in relation to their impact on some internal quality parameters. Alex. Sci. Exch. 16 (3): 389-404.

Radwan, S. S. 1978. Coupling of two dimention thin layer chromatography with gas chromatography for the quantitative analysis of lipids classes and their constituent fatty acids. J. Chromatog. Sci. 16: 538-542.

Ramadan, R. A. 1991. Residues of profenofos and pirimiphos-methyl in tomato and okra fruits as influnced by certain technologieal processes. 4th Net. Conf. of Pests and Dis. of Veg \& Fruits, Ismallia, Egypt, pp. 303-316.

Soliman, M. M. M. 1994. Efficiency of some insecticides against leguminous pod borer Etiella Zinckenella Treitschke on cowpea with special reference to pesticide residues. M. Sc. Thesis, Fac. Agric. Cairo Univ., Egypt.

Steel, R. G. D. and J. H. Torrie. 1980. Principles and procedures of statistics. A biometrical approach. 2nd ed. McGrawHill Kogakusha, Ltd., pp. 633.

Thomas, W. and R. A. Dutcher. 1924. Picric acid method for carbohydrate. J. Amer. Chem. Sci. 46: 1662-166. 